\title{
Habitat suitability - density relationship in an endangered woodland species: the case of the Blue Chaffinch (Fringilla polatzeki)
}

\author{
Luis M. Carrascal ${ }^{\text {Corresp., }}{ }^{1}$ ，Angel C. Moreno ${ }^{2}$, Alejandro Delgado ${ }^{3}$, Víctor Suárez $^{3}$, Domingo Trujillo ${ }^{3}$ \\ 1 Department of Biogeography \& Global Change, Museo Nacional de Ciencias Naturales, CSIC, Madrid, Spain \\ 2 Viceconsejería de Medio Ambiente, Gobierno de Canarias, Dirección General de Protección de la Naturaleza, Las Palmas de Gran Canaria, Spain \\ 3 Wildlife Freelance, Las Palmas de Gran Canaria, Spain \\ Corresponding Author: Luis M. Carrascal \\ Email address: Imcarrascal@mncn.csic.es
}

Background. Understanding constraints to the distribution of threatened species may help to ascertain whether there are other suitable sectors for reducing the risks associated with species that are recorded in only one protected locality, and to inform about the suitability of other areas for reintroduction or translocation programs.

Methods. We studied the Gran Canaria blue chaffinch (Fringilla polatzeki), a habitat specialist endemic of the Canary Islands restricted to the pine forest of Inagua, the only area where the species has been naturally present as a regular breeder in the last 25 years. A suitability distribution model using occurrences with demographic relevance (i.e., nest locations of successful breeding attempts analysed using boosted classification trees) was built considering orographic, climatic and habitat structure predictors. By means of a standardized survey program we monitored the yearly abundance of the species in 100 sectors since the declaration of Inagua as a Strict Nature Reserve in 1994.

Results. The variables with the highest relative importance in blue chaffinch habitat preferences were pine height, tree cover, altitude, and rainfall during the driest trimester (July-September). The observed local abundance of the blue chaffinch in Inagua (survey data) was significantly correlated with habitat suitability derived from modelling the location of successful nesting attempts (using linear and quantile regressions). The outcomes of the habitat suitability model were used to quantify the suitability of other natural, historic, pine forests of Gran Canaria. Tamadaba is the forest with most suitable woodland patches for the species. We estimated a population size of 195-430 blue chaffinches in Inagua since 2011 $(95 \% \mathrm{Cl})$, the smallest population size of a woodland passerine in the Western Palearctic.

Discussion. Habitat suitability obtained from modelling the location of successful breeding attempts is a good surrogate of the observed local abundance during the reproductive season. The outcomes of these models can be used for the identification of potential areas for the reintroduction of the species in other suitable pine forests and to inform forest management practices. 
1 Habitat suitability - density relationship in an endangered woodland species: the case of 2 the Blue Chaffinch (Fringilla polatzeki)

3 Luis M. Carrascal $^{1 *}$, Ángel C. Moreno ${ }^{2}$, Alejandro Delgado ${ }^{3}$, Víctor Suárez ${ }^{3}$, Domingo Trujillo ${ }^{3}$

4

5 1: Department of Biogeography and Global Change. Museo Nacional de Ciencias Naturales-

6 C.S.I.C. C/ José Gutiérrez Abascal 2, 28006. Madrid, Spain.

7 2: Dirección General de Protección de la Naturaleza, Viceconsejería de Medio Ambiente,

8 Gobierno de Canarias, Las Palmas de Gran Canaria, Canary Islands, Spain.

9 3: Wildlife Freelance, Las Palmas de Gran Canaria, Spain

10

11 *: Corresponding author. E-mail address: 1mcarrascal@mncn.csic.es (L.M. Carrascal).

13 Short Title: Habitat suitability and population density 


\section{ABSTRACT}

15 Background. Understanding constraints to the distribution of threatened species may help to ascertain whether there are other suitable sectors for reducing the risks associated with species that are recorded in only one protected locality, and to inform about the suitability of other areas for reintroduction or translocation programs.

Methods. We studied the Gran Canaria blue chaffinch (Fringilla polatzeki), a habitat specialist endemic of the Canary Islands restricted to the pine forest of Inagua, the only area where the species has been naturally present as a regular breeder in the last 25 years. A suitability distribution model using occurrences with demographic relevance (i.e., nest locations of successful breeding attempts analysed using boosted classification trees) was built considering orographic, climatic and habitat structure predictors. By means of a standardized survey program we monitored the yearly abundance of the species in 100 sectors since the declaration of Inagua as a Strict Nature Reserve in 1994.

Results. The variables with the highest relative importance in blue chaffinch habitat preferences were pine height, tree cover, altitude, and rainfall during the driest trimester (July-September). The observed local abundance of the blue chaffinch in Inagua (survey data) was significantly correlated with habitat suitability derived from modelling the location of successful nesting attempts (using linear and quantile regressions). The outcomes of the habitat suitability model were used to quantify the suitability of other natural, historic, pine forests of Gran Canaria.

33 Tamadaba is the forest with most suitable woodland patches for the species. We estimated a 34 population size of $195-430$ blue chaffinches in Inagua since 2011 (95\% CI), the smallest population size of a woodland passerine in the Western Palearctic. 
36 Discussion. Habitat suitability obtained from modelling the location of successful breeding

37 attempts is a good surrogate of the observed local abundance during the reproductive season. The

38 outcomes of these models can be used for the identification of potential areas for the

39 reintroduction of the species in other suitable pine forests and to inform forest management

40 practices. 


\section{INTRODUCTION}

42 Habitat suitability is usually determined by the relationship between environmental predictors 43 and species occurrence or abundance (Acevedo et al., 2016). Using species occurrence to 44 understand the suitability of habitat is commonly employed when studying very scarce and 45 spatially restricted species. In the case of very mobile species, such as birds, the localities where 46 they have been observed may include areas that are important for their existence (e.g., space 47 around nesting places), as well as other marginal areas used while dispersing or foraging outside 48 the core home range. Thus, the utility of species occurrence models rests on the availability of good data on local species distribution, which will be all the better as the localities are linked to processes directly related to survival or breeding success. On the other hand, analysis of the spatial variation of abundance may pose problems, since several authors have warned that density could be a misleading indicator of environmental quality if it is negatively correlated with other demographic variables via Ideal Pre-emptive Distribution processes (Van Horne, 1983; Pulliam \& Danielson, 1991; Brawn \& Robinson, 1996). For example, in environmentally restrictive areas, dominant individuals could displace other young or subordinate individuals to marginal areas where they become abundant, not as a consequence of habitat tracking

57 considering foraging success, survival or successful reproduction, but according to mere habitat 58 displacement. Therefore, in order to obtain good predictions about habitat suitability for selecting areas to protect remnant populations of endangered species, or for defining habitat for 60 translocation, it is necessary to maximize data quality related to survival or breeding success.

61 Furthermore, it is also necessary to know if habitat quality inferred from local abundance is 62 associated with other independent measures related to suitability linked with demography 63 (Vickery et al., 1992). The "habitat suitability - abundance" equivalence is a subject of intensive 
64 research because independent tests are needed to ascertain the validity of predictions of species

65

66

67

68

occurrence models, considering that presence data are much easier to obtain than local measures of density (Jiménez-Valverde, 2011; Weber et al., 2017).

Natural reserves are established to protect the whole biodiversity or those threatened species that have conservation problems (Geldmann et al., 2013). Nevertheless, their effectiveness may vary if phenomena outside the borders of the protected areas affect populations inside them (e.g., global warming and changes in rainfall regime, emergent diseases, invasive species), a worrying concern if species are restricted to only one protected area. This concern is a relevant question contributing to knowing whether it is advisable to place the emphasis on the conservation of an endangered species in only the protected area where it is relegated, or if more efforts should be directed towards translocations to other areas (Pérez et al., 2012; Rummel et al., 2016). To identify those other potential areas it is necessary to know constraints to the distribution of species restricted to only one protected area, in order to know if there are other suitable sectors for reducing the risks associated with the presence of an endangered species in only one locality (an IUCN criteria for cataloging threat; IUCN, 2012).

The blue chaffinch of the Gran Canaria island (Fringilla polatzeki, Canary Islands) is a recently established species on the basis of genetic, morphological and behavioural data (Pestano et al., 2000; Lifjeld et al., 2016; Sangster et al., 2016), mainly restricted to the Strict Nature Reserve of Inagua-Ojeda-Pajonales (Inagua, hereafter; $39.2 \mathrm{~km}^{2}$; Moreno and Rodríguez, 2007). It inhabits mature pine forests, where nests are placed in tall trees; breeding success is very low for a Fringillidae, with only ca. 1.5 fledglings per successful nesting attempt, and 1.4 clutches per breeding season (Rodríguez \& Moreno, 2008; Delgado et al., 2016). The estimated population size of the Gran Canaria blue chaffinch (guessed at around 300 birds with no recent estimation in 
87 its whole area of distribution, BirdLife International, 2016a) lies within the left tail of the 88 distribution of minimum viable population (MVP) estimates for many species, far away from the average MVP of 3,750 individuals for birds (Brook et al., 2006; Traill et al., 2007). This is most notable if we take into account the small size of the species (approx. $30 \mathrm{~g}$ ), since body mass in birds is usually negatively correlated with abundance or maximum ecological densities in preferred habitats (Carrascal \& Tellería, 1991; Gaston \& Blackburn, 2000). Surprisingly, and in spite of its low population size and smaller distribution area in comparison with the also endemic blue chaffinch from Tenerife island (Fringilla teydea; Rodríguez \& Moreno, 2004; Moreno \& Rodríguez, 2007), it has a higher haplotype diversity of the mitochondrial DNA control region (Pestano et al., 2000).

The main goals of this study are twofold. Firstly, to build a species occurrence distribution model considering orographic, climatic and habitat structure predictors. This goal is carried out relying on high-quality occurrence data, using the location of successful breeding attempts. The results of this model are used to contrast the habitat preferences of the Gran Canaria $(F$. polatzeki) and Tenerife $(F$. teydea $)$ blue chaffinches considering the available literature, and to predict the habitat suitability of the natural and historic pine forests of Gran Canaria located within the same altitudinal range of Inagua. An applied utility of this aim is to understand if there are important environmental restrictions limiting the natural presence of the blue chaffinch outside of Inagua, and to quantify the suitability of other historic pine forests on Gran Canaria as candidates for future translocations of birds. And secondly, to test if habitat suitability modelling, considering the location of successful nesting attempts, is related to independent measures of bird abundance during the breeding season using a different methodological approach. This exercise would cast light on the usefulness of occurrence 
110 distribution models, using labour-intensive occurrences with demographic relevance, forecasting

111 the spatial variation of habitat suitability, and the validity of survey programs to derive estimates

112 of environmental quality.

113

114

115

116

117

118

119

120

121

122

123

124

125

126

127

128

129

130

131

132

\section{MATERIAL AND METHODS}

\section{Study areas and environmental data}

The study areas are located in several pine forests of Gran Canaria $\left(27^{\circ} 58^{\prime} \mathrm{N}, 15^{\circ} 35^{\prime} \mathrm{W}\right)$, an island of volcanic origin $\left(1560 \mathrm{~km}^{2}\right.$, maximum altitude of $1950 \mathrm{~m}$.a.s.1.; for more details on the vegetation of the island see Santos, 2000). The canary pine forests are dry and monospecific stands of Pinus canariensis, very heterogeneous regarding the size and cover of trees and undergrowth (mainly composed by Leguminosae shrubs Adenocarpus spp. and Chamaecytisus proliferus, and the Ericaceae shrubs Erica arborea and E. scoparia), occupying semi-arid hilly terrains comprised of a predominance of high slopes and rugged terrain (González et al., 1986).

The main study area is located in the pine forest of Inagua Integral Natural Reserve (37.59 km² with nearby pine stands; Special Protection Area of the European Union since 1979), which harbours the main extant breeding population of the blue chaffinch (Moreno \& Rodríguez, 2007). Location of nests and yearly monitoring of blue chaffinch abundance were carried out in Inagua. For evaluating the habitat suitability of other mature pine forests within the environmental span of Inagua, we also considered the pine forests of Tamadaba $\left(28.12 \mathrm{~km}^{2}\right)$, Pilancones $\left(31.67 \mathrm{~km}^{2}\right)$ and Tauro $\left(4.70 \mathrm{~km}^{2}\right)$. Fig. 1, Table S1 and Figures S1, S2 and S3 of the supplementary material show the geographical location of the study areas and their environmental characteristics. The four pine forests show a broad overlap in orographic 
133 attributes, with all cardinal orientations represented: altitudinal range of the studied pine forests

134 is 250 - $1550 \mathrm{~m}$ a.s.1., slopes of the terrain varies between $0 \%$ and $260 \%$ (with very steep 135 averages of 45\%-55\%). Pine canopy cover ranges between $0 \%$ (clearings) and 99\%, with 136 Tamadaba forest being the area with the largest cover (43\%). Pine height also shows a large 137 overlap among the four pine forests, with the tallest pines reaching $40 \mathrm{~m}$ in Inagua. The shrub 138 layer shows similar structural characteristics in the four pine forests, with average covers ca. $13910 \%$ (maximum of $75 \%$ ) and heights ca. $0.7 \mathrm{~m}$ (maximum values of $1.25 \mathrm{~m}$ ). Climatic variables 140 considerably overlap among the study areas, with high levels of average incident sun radiation 141 during April-August (ca. $7000 \mathrm{kWh} / \mathrm{m}^{2}$; minimum of 4567 and maximum of 7515), high average 142 temperatures in May (ca. $19^{\circ} \mathrm{C}$; minimum: $17.0^{\circ} \mathrm{C}$; maximum: $21.2^{\circ} \mathrm{C}$ ) and July (ca. $24.5^{\circ} \mathrm{C}$; 143 minimum: $23.6^{\circ} \mathrm{C}$; maximum: $25.9{ }^{\circ} \mathrm{C}$ ), and low summer rainfall (July-September) ranging from $1440 \mathrm{~mm}$ to $34 \mathrm{~mm}$ (Tamadaba is the pine forest with the highest rainfall, mainly horizontal 145 precipitation, while Pilancones is the driest pine forest).

A severe fire occurring in July 2007 badly affected the Inagua Reserve, Pilancones and 147 Tauro, but not the Tamadaba forest (see Fig. 1 in Suárez et al., 2012). The Canary Pine has the 148 remarkable characteristic of being able to survive and grow after fire. In most places the pine 149 foliage was partially recovered by June 2008, and the tree foliage showed full growth by the 150 breeding season of 2010. The geographic information was managed using the GRASS 6.4 (GRASS

152 Development Team, 2015). The cartographic information employed to generate the digital 153 terrain model comes from the "Infraestructura de Datos Espaciales de Canarias" 154 (http://www.idecanarias.es/). The digital elevation model was built from a contour map with 5-m 155 equidistant topographic curves which was converted to a raster map of 50x50 m resolution, with 
156 module $\{$ v.to.rast $\}$ and $\{$ r.surf.contour $\}$. From the digital terrain model, raster maps of slopes of

157 the terrain, and cardinal orientations of the hillsides, were elaborated at $50 * 50 \mathrm{~m}$ resolution by

158 means of the module \{r.slope.aspect\}. Climatic variables were obtained from the "Clima-

159 Impacto" project (http://climaimpacto.eu/), developed by the Gobierno de Canarias and funded

160 by the European Regional Development Fund of the European Union, at a raster resolution of

$16150 * 50 \mathrm{~m}$. Vegetation structure variables (pine and shrubs covers and heights) were obtained from

162 precision laser LiDAR measurements. Data was provided at a raster resolution of $25 * 25 \mathrm{~m}$ by the

163 project "Enriquecimiento de la Cartografia de las islas forestales de Canarias a partir de datos

164 LIDAR" (GESFORMAC -Gestión y Planificación Forestal en la Macaronesia-, funded by

165 European Regional Development Fund and by Dirección General de Protección de la Naturaleza

166 del Gobierno de Canarias). These vegetation LiDAR measurements were upscaled to a resolution

167 of $50 * 50 \mathrm{~mm}$ using the module $\{$ r.resample $\}$. Finally, solar radiation data were obtained from the

168 photovoltaic potential maps in the Canary Islands (http://www.idecanarias.es/), partially funded

169 by the Spanish Ministry of Industry, Tourism and Commerce, and by the European Regional

170 Development Fund.

171

172 Bird survey and nest location of blue chaffinches

173 Data on bird counts was obtained from line-transect sampling in Inagua during the

174 breeding season (second fortnight of May and the first fortnight of June; see Rodríguez and

175 Moreno, 2008) from 1994 to 2016 in 15 different years. A fixed network of trails of a total length

176 of $22.9 \mathrm{~km}$ has been surveyed using the same methodology since 1994 (see Fig. 1). From 1994 to

177 2006, a transect of $22.9 \mathrm{~km}$ was surveyed one time per year; from 2011 to 2016, the transect was

178 repeated three times on different days to obtain more reliable results (i.e., using the average of 
179 the three surveys). Transects were carried out on windless and rainless days, walking along

180 single tracks at a low speed (1-3 km/h approximately), during the first four hours after dawn.

181 Different persons carried out the surveys: A.C.M. from 1994 to 2004; V.S and A.D, in 2006,

182 2011-2016. To account for inter-personal and between-year variation in detectability while

183 collecting counts, we employed distance sampling methods (Buckland et al., 2007). For each

184 bird heard or seen, the perpendicular distance to the observer's trajectory was estimated.

185 Previous training helped to reduce inter-observer variability in distance estimates. Detection

186 distances were right-truncated, excluding 5\% of birds recorded far away (i.e. beyond $125 \mathrm{~m}$ ).

187 The total length of transects were divided in 100 contiguous units of equal length (229 $\mathrm{m})$, to

188 which the detected blue chaffinches were averaged across years, accounting for detection 189 probability.

Intensive surveys of the Inagua pine forest during 2011 to 2016 allowed the location of

191

192

193

194

195

196

197

198

199

200

201

active nests (carried out by V.S., A.D. and D.T.). We restricted sampled nests used in analyses to those years when the pine forest had recovered after the forest fire of July 2007. Although searches were mainly carried out around the area covered by the fixed network of trails where the monitoring program was conducted, other sectors covering the whole Inagua reserve were surveyed while moving around to access those trails (by foot and by vehicle on dirt tracks). Nests were located by following individuals during the prelaying and incubation period (mainly by females), by means of audible begging calls by nestlings, or by observing parents feeding bouts to chicks (see Rodríguez \& Moreno, 2008 for more details on nest location and the breeding biology of the blue chaffinch in Inagua). Nests were monitored every 3-5 days in order to establish the successful reproduction of each breeding pair. We considered a successful breeding attempt when at least one fledgling was produced in the focal nest. Fifty-nine successful nests 
202 were recorded: 16 in 2011, 12 in 2013, 16 in 2014, 15 in 2016. They were found within an area 203 of $24.2 \mathrm{~km}^{2}(2.6 * 9.2 \mathrm{~km}$ in latitude and longitude geographical dimensions). Altitudinal range of 204 nest locations was 860-1485 m a.s.1., within a broad spectrum of orographic conditions regarding 205 the cardinal orientation and the slope of the terrain (see Table S1 of the supplementary material).

206 The Consejería de Medio Ambiente del Cabildo de Gran Canaria gave access to carry out all the 207 field work under the LIFE14 NAT/ES/000077.

208

\section{Data analyses}

Detectability models for the blue chaffinch were built with the $\mathrm{R}$ packages $\{$ Distance $\}$ (Miller, 2016a) and $\{m r d s\}$ (Miller, 2016b) under R version 3.1.2 (R Core Team, 2014). Population density of the blue chaffinch in Inagua was calculated considering the counts of birds in the $22.9 \mathrm{~km}$ transect and the effective strip width (ESW) derived from the probability of 214 detection.

Breeding habitat suitability for the blue chaffinch in Inagua was modelled using boosting classification trees (BCT) with the occurrence of the species denoted as nest locations where successful breeding occurred. Boosting trees are a statistical learning method that attains both accurate predictions and good explanations for regression and classification problems, dealing with many types of response and predictor variables (numeric or categorical) and loss functions (Gaussian, binomial, Poisson), and managing parsimoniously complex interactions among predictors (De'Ath, 2007; Elith et al., 2008). Boosting trees algorithm aims to improve model accuracy by fitting several trees in a stage-wise process in which the first tree focuses on the raw data, the second tree on the residuals from the first tree, and so on. Final predictions are made through model averaging. 
BCT models were built and summarizing using the R packages $\{g b m\}$ (Ridgeway, 2016),

226

227

228

229

230

231

232

233

234

235

236

237

238

239

240

241

242

243

244

245

246

247

$\{$ dismo $\}$ (Hijmans et al., 2016), $\{R O C R\}$ (Sing et al., 2015) and \{psych\} (Revelle, 2016). Model

parameters were: bag fraction of $2 / 3$, learning rate of 0.001 , tree complexity of 5 (a maximum model complexity of 11 nodes-leaves and five splitting criteria), and minimum of 5 sampling units per inner node. We used a ten-fold approach in order to test the accuracy of predictions of BCT models. The discrimination ability of BCT models was estimated through the area under the curve (AUC) of the receiver operating characteristic (ROC) plot of sensitivity against 1specificity.

The environmental characteristics of the cells of $50 * 50 \mathrm{~m}$ in which the successful nests were located ( $=59$; "breeding success", level 1 of a binomial distribution) were compared with those measured in an identical number of 50*50 m cells randomly obtained from the background of Inagua (59 out of 15,037 cells obtained by means of resampling without replacement; "available habitat", level 0 of a binomial distribution; see predictor variables in Table S1 of Supplementary material). Moreover, to obtain a more robust approximation to the habitat occupancy during reproduction, bootstrapped samples of the fifty-nine $50 * 50 \mathrm{~m}$ cells with successful breeding were obtained (i.e., resampling with replacement to avoid outliers). This analytical approach is associated with the classic, and well-established, study of habitat selection in which habitat use is compared against habitat availability (Cody, 1985; Wiens, 1989), in such a way that the sample size of the availability records is determined by the sample size recorded for the individuals under study. Moreover, this approach shows good statistical properties in comparison with other presence-only analyses (Barbet-Massin et al., 2012; see also Warton \& Aarts, 2013). BCT predictions ( $p$ ) around 1 denote that the $50 * 50 \mathrm{~m}$ cells have environmental characteristics very similar to those shown by the nest locations with blue finch successful 
248 reproduction. Conversely, BCT predictions around 0 are related to $50 * 50 \mathrm{~m}$ cells with extremely

249 different environmental characteristics for the successful reproduction of the species. And

250 finally, when $p=0.5$, the environmental characteristics of the $50 * 50 \mathrm{~m}$ cells are similar to the

251 average of the habitat use and habitat availability samples.

252 We repeated the BCT models 20 times, using different bootstrap samples of the $50 \times 50 \mathrm{~m}$

253 cells characterizing the habitat of the 59 breeding successful nests, and different random samples

254 of 59 background cells of $50 * 50 \mathrm{~m}$. The values obtained with these 20 models were averaged

255 (accuracy parameters, relative importance of the 12 predictor variables, partial effects of each

256 variable, and predictions for all 50*50 cells in Inagua, Tamadaba, Pilancones and Tauro).

BCT predictions of habitat suitability for the successful breeding of the blue chaffinch in

258 the one-hundred $229-\mathrm{m}$ transect units, of the abundance monitoring transect, were obtained by

259 averaging the nearest sixteen $50 * 50 \mathrm{~m}$ cells (estimated by means of the Euclidean distance).

260 Habitat suitability in these 100 transect units were regressed upon the average number of blue

261 chaffinch counted in those years after the pine forest recovered from the forest fire of July 2007

262 (i.e., 1994-2006 and 2011-2016; 15 years considered). The spatial eigenvector mapping analysis

263 (SEVM) was carried out to account for spatial autocorrelation in the 100 transect units (Diniz-

264 Filho \& Bini, 2005; Dorman et al., 2007). SEVM is based on the idea that spatial arrangement of

265 sample locations can be translated into explanatory variables that capture spatial effects, by

266 means of the eigenfunction decomposition of the spatial connectivity matrix among the 100

267 transect units of $229 \mathrm{~m}$. SEVM produced three spatial filters that reduced the spatial 268 autocorrelation in the residuals of the regression model of chaffinch abundance on predicted

269 habitat suitability for successful breeding (i.e., the residuals showed nonsignificant figures of

270 spatial autocorrelation according to Moran's I). SEVM was carried out using SAM package (v. 
2714.0 ; Rangel et al., 2010). Due to deviations from homoscedasticity of the residuals across the

272 predictions of the SEVM model, we used the heteroscedasticity-corrected coefficient covariance

273 matrix to obtain the proper significance of habitat suitability and the three spatial filters (Zeileis,

274 2004); the HC4m estimator suggested by Cribari-Neto (2004) was used to further improve the

275 performance in significance estimations, especially in the presence of influential observations

276 under small sample sizes (using the R package \{sandwich\}, Lumley and Zeileis, 2015). Quantile

277 regression of bird abundance against habitat suitability was carried out using \{quantreg\} package

278 (Koenker, 2016), applying the bootstrapping approach for estimating standard errors and 279 significance.

The probable population size of the blue chaffinch in Inagua was estimated considering 281 the suitability predictions in cells of $200 * 200 \mathrm{~m}^{2}$ (joining sixteen $50 * 50 \mathrm{~m}^{2}$ cells), the relationship between habitat suitability and local abundance of the blue chaffinch in 2011-2016 (see above; i.e., the equation converting the probability of occurrence in bird numbers), and the detectability in the period 2011-2016 (number of blue chaffinches corrected for detectability bias $=$ predicted number of chaffinches divided by 0.56 ). We calculated the probable population size of the species in Inagua adding up the predictions of bird numbers in the sample of $200 * 200 \mathrm{~m}^{2}$ cells. The $95 \%$ confidence interval of the predictions was estimated by means of percentiles (i.e., $2.5 \%$ and $97.5 \%$ ), after bootstrapping the probable number of birds in the $200 * 200 \mathrm{~m}^{2}$ cells (1000 bootstraps).

RESULTS

\section{Breeding habitat selection and habitat suitability modelling}


The boosted classification tree models (BCT) produced highly accurate results,

295

296

297

298

299

300

301

302

303

304

305

306

307

308

309

310

311

312

313

314

315

316

considering sensitivity (0.999), specificity (0.979), 10-fold cross-validation AUC (0.905), and positive (0.979) and negative (0.999) predictive success figures (see Table 1 for more details regarding the results of the 20 randomized runs of the BCT models, each time with a different random sample of background 50*50 m cells). The variables with the highest relative importance in the BCT models were pine height (relative importance adding up to $100 \%=26.4$ ), tree cover (19.2), altitude (13.7), and rainfall during the driest trimester (July-September; 11.7). The remaining eight predictors had relative importance lower than that expected considering the number of predictors $(100 / 12=8.3)$. Table 2 shows the results for the relative importance of predictors in 20 runs of the BCT models, and Fig. 2 shows the partial dependence plots for the four most influential variables.

Habitat suitability for successful breeding steadily increased with pine height from 15 to $20 \mathrm{~m}$ (remaining stably high above the second value), with tree cover from $25 \%$ to $37 \%$ (the partial influence of tree cover was at random when cover was higher than 55\%), with altitude from 1100 to $1280 \mathrm{~m}$ a.s.l. (remaining stably high above the second value), and from 13 to 20 $\mathrm{mm}$ of summer rainfall. Habitat suitability in Inagua was very low in sectors with $<17 \mathrm{~m}$ of pine height, $<30 \%$ of tree cover, at altitudes $<1100 \mathrm{~m}$ a.s.l. and at locations with $<13 \mathrm{~mm}$ of precipitation during July-September. Mean habitat suitability in the forest patches with those characteristics was very low $(0.029, \mathrm{sd}=0.019$, interquartile range: $0.018-0.030, \mathrm{n}=2285$ cells $)$. Conversely, habitat suitability reached the highest figures in woodland sectors located between 1200 and $1550 \mathrm{~m}$ of altitude, with pines taller than $20 \mathrm{~m}$ covering $37-50 \%$ of the area, and with a summer precipitation of 18-24 mm. Average habitat suitability in these favourable forest patches was very high $(0.827, \mathrm{sd}=0.083$, interquartile range: $0.781-0.889, \mathrm{n}=261$ cells $)$. 
318 the pine forests of Gran Canaria island located within the altitudinal range of the study area in

319

320

321

322

323

324

325

326

327

328

329

330

331

332

333

334

335

336

337

338

339

which the BCT models were built. The results of the predicted suitability for the pine forests of Inagua, Tamadaba, Pilancones and Tauro are presented in Fig. 3, and with more detail in the Figures S1-S3 of the supplementary material. Habitat suitabilities of pine forests are summarized in Fig. 4 according to the area in an increasing scale of suitability levels. Inagua is the pine forest with the largest surface for the successful breeding of the blue chaffinch $\left(7.95 \mathrm{~km}^{2}\right.$ with a suitability $>0.5)$, followed by Tamadaba pine forest $\left(3.89 \mathrm{~km}^{2}\right)$ and Pilancones $\left(0.42 \mathrm{~km}^{2}\right)$; Tauro forest lacks suitable habitat for the reproduction of the species. This pattern of among forests differences in habitat suitability becomes more skewed when considering higher levels of habitat suitability; e.g., with suitability $>0.8$, there are $2.09 \mathrm{~km}^{2}$ in Inagua, $0.48 \mathrm{~km}^{2}$ in Tamadaba and a complete lack of habitat in Pilancones and Tauro. Moreover, there is more contiguity of woodland patches with high levels of habitat suitability, and their sizes are larger, in Inagua than in Tamadaba (compare smoothed values of suitability $>0.5$ in Figures $\mathrm{S} 1$ and $\mathrm{S} 2$ of the supplementary material). Finally, the proportion of pine forest surface with very low habitat suitability (e.g., <0.2) decreased according to the following order: Pilancones $(92.1 \%)$, Tauro $(89.2 \%)$, Tamadaba (62.5\%) and Inagua (57.5\%). Summarizing, Inagua reserve, the classical pine forest with historic and continuous presence of the blue chaffinch, has the largest potential area of the most favourable habitat for the successful breeding of the species, with larger and less fragmented suitable woodland patches, and with the lowest proportion of unfavourable breeding habitat. The pine forest of Tamadaba, with scarce presence of the blue chaffinch in the last 60 years, also provides suitable woodland patches for the species, although the amount of highly favourable habitat is lower, and its patchiness higher, than that obtained for Inagua. The pine 
340 forests of Pilancones and Tauro have an extremely low habitat suitability for the successful

341 breeding of the species.

\section{Relationship between local abundance and predicted habitat suitability}

BCT models in 100 units of the same $22.9 \mathrm{~km}$ survey trail in Inagua reserve, and the mean

number of blue chaffinches counted in the breeding season during 15 years in those units (19942006 and 2011-2016, considering those years when the pine forest was not affected by the devastating forest fire of July 2007; Fig. 5). The linear model obtained taking into account three spatial autocorrelation filters (that reduced the spatial autocorrelation in the residuals of the model according to Moran's I) was highly significant: $\mathrm{R}^{2}=42.5 \%, \mathrm{~F}_{4,95}=17.55, \mathrm{p}<<0.001$. The partial contribution of the spatial filters (i.e., spatial component) to total variance in blue chaffinch counts was $19.2 \%$, that attributable to predicted suitability was $15.3 \%$, while $8 \%$ was the shared contribution of both sets of predictors. The partial effect of the habitat suitability on finch counts was highly significant (partial slope $=0.661$, heteroskedastic-corrected standard error $=0.151, \mathrm{p}<<0.001)$. This relationship depicts an increasing error variance. In fact, a quantile regression analysis shows that the slope progressively increases from $10 \%$ to $50 \%$ to $90 \%$ percentiles $(\mathrm{tau}=0.1, \mathrm{~b}=0.367, \mathrm{se}=0.187, \mathrm{p}=0.053 ;$ tau $=0.5, \mathrm{~b}=0.491, \mathrm{se}=0.214, \mathrm{p}=$ $0.0243 ;$ tau $=0.9, \mathrm{~b}=0.760, \mathrm{se}=0.251, \mathrm{p}=0.003 ;$ taking into account the three spatial autocorrelation filters). Thus, two different sets of habitat preference measures were highly correlated, showing that for a passerine species with a low population density, such as the blue chaffinch in Gran Canaria, local estimations of abundance are positively related to habitat suitability for successful breeding. 
$364(\mathrm{pDET})=0.64, \mathrm{se}=0.12$, sample size $(\mathrm{N})=345$ bird contacts; Years 2006, 2011-2016: $\mathrm{pDET}=$

3650.56 , se $=0.09, \mathrm{~N}=385$. Considering the suitability map of Fig. 3 (joining sixteen $50 * 50 \mathrm{~m}^{2}$

366 cells into $200 * 200 \mathrm{~m}^{2}$ cells), the relationship between habitat suitability and local abundance of

367 the blue chaffinch in 2011-2016 (very similar to that depicted in Fig. 5; partial slope $=0.780$,

368 heteroskedastic-corrected standard error $=0.194, \mathrm{p}=0.001)$, and the detectability in the period

369 2011-2016 (probability of detection $=0.56$ ), we calculated the probable population size of the

370 species in Inagua. The mean estimate is 279 birds, with a 95\% confidence interval of 195-430

371 chaffinches.

\section{DISCUSSION}

\section{Relationship between local abundance and predicted habitat suitability}

Studies aimed at predicting species abundance from species occurrence distribution models have yielded mixed results (e.g., Conlisk et al., 2009; Jiménez-Valverde et al., 2009; Yañez-Arenas et al., 2014; Carrascal et al., 2015; Basile et al., 2016). A recent meta-analysis 379 (Weber et al., 2017) concluded that occurrence data can be a reasonable proxy for abundance, especially if local environmental variables are considered when dealing with the abundancesuitability relationship. Our results show that the observed local abundance of the blue chaffinch in Inagua (survey data) correlated with habitat suitability derived from modelling the location of successful breeding attempts. The relationship was relatively triangular (Fig. 5), denoting the asymmetric relationship between these two parameters: unsuitable woodland sectors can only have low blue chaffinch abundances, whereas very favorable sites can have high or low 
387 of other important factors responsible for the emergence of the triangular positive relationship,

388 such as the "unsaturation" of the available habitat (i.e., there are not enough blue chaffinches to 389 occupy the favorable woodland patches) or other unmodelled habitat features. For example, 390 García-del-Rey et al. $(2009,2010)$ have shown the importance of structure and species identity 391 of the shrub layer during the breeding season, as well as pine seed availability on the ground for 392 feeding habitat selection during winter in F. teydea of Tenerife island. On the other hand, survey 393 counts at very small spatial scales may be accounting for the mere presence of floaters or 394 breeders outside the core area of the nesting place, as chaffinches (especially males) spend a 395 considerable amount of time outside the breeding territories (e.g., Hanski \& Haila, 1988 with 396 Fringilla coelebs). Conservation biologists are warned to be cautious when relying on abundance 397 estimations as surrogates of habitat quality (Van Horne, 1983), which is more accurately 398 described with labor-intensive demographic research (Johnson, 2007). Nevertheless, our results suggest that local abundance is a good surrogate of environmental quality for successful nesting 400 in the blue chaffinch, which agrees with other previous studies showing that birds are usually

401

402

403

404

405

406

407

408

409

more abundant in habitats where per capita reproduction is highest (e.g., review by Bock \& Zach, 2004; Carrascal \& Seoane, 2009).

\section{Population size}

In spite of the imperfect fit between habitat suitability for successful nesting and local bird abundance, regional abundance can be accurately predicted in an unbiased way from occurrence distribution models by the aggregation of local predictions, whose overpredictions and underpredictions can be counteracted (see Carrascal et al., 2015 for 21 terrestrial bird species in La Palma, Canary islands). Thus, the species occurrence distribution models can be used as a 
410 cost-effective tool to provide tentative population estimations when data from exhaustive census

411 programs are not available. We estimated an exiguous population size of ca. 280 blue

412 chaffinches in Inagua, which is consistent with its low population density and the small area of

413 this pine forest $\left(37.6 \mathrm{~km}^{2}\right)$. Although the topic merits an exhaustive census program, this

414 assessment should be considered as a first approximation to the population estimation in Inagua.

415 Another 38 blue chaffinches can be added to those low numbers (minimum estimation;

416 Rodríguez, 2016), given the recently established small population located at higher altitudes in

417 La Cumbre $\left(20.7 \mathrm{~km}^{2}\right.$; from a captive breeding and translocation program; Delgado et al., 2016;

418 Rodríguez, 2016). Therefore, with $\sim 320$ individuals in $58.3 \mathrm{~km}^{2}$ of pine forests during the

419 breeding season, the Gran Canaria blue chaffinch is the passerine with the lowest population size

420 in the Western Palearctic (average density: 5.5 birds $/ \mathrm{km}^{2}$ ). This population size is several times

421 lower than that recorded for the other three specialists species of marginal woodlands with very

422 small populations: Sitta whiteheadi (5500 individuals in ca. $185 \mathrm{~km}^{2}, 29.7$ birds/km²; BirdLife

423 International, 2016b), Phyrrula murina (1000 individuals in ca. $100 \mathrm{~km}^{2}, 10.0$ birds $/ \mathrm{km}^{2}$;

424 BirdLife International, 2016c), and Sitta ledanti (350-1500 individuals in ca. $700 \mathrm{~km}^{2}, 0.5-2.0$

425 birds $/ \mathrm{km}^{2}$; BirdLife International, 2016d). Although the population size of the blue chaffinch is

426 considerably lower than minimum viable population sizes suggested for birds (around 3500

427 individuals for a persistence probability of 99\% in 40 generations; Brook et al., 2006; Traill et

428 al., 2007), its persistence with relatively constant numbers in Inagua during the last several years

429 probably shows its high resilience against demographic risk factors. Nevertheless, it could very

430 well be that the stochastic variability of the environment has been rather benign during the last

431 century, and this trend may not continue in the future, thus qualifying the Gran Canaria blue

432 chaffinch as an endangered or critically endangered habitat specialist. 
434

435

436

437

438

439

440

441

442

443

444

445

446

447

448

449

450

451

452

453

454

455

\section{Breeding habitat selection}

Habitat preferences for successful breeding of the Gran Canaria blue chaffinch are similar to those measured in its sibling species from the nearby Tenerife island, although Fringilla polatzeki shows a remarkably lower altitudinal range and a higher preference for mature pine stands. Fringilla teydea ranges from 1000 to $2060 \mathrm{~m}$ a.s.1., reaching in the $1500-2000 \mathrm{~m}$ belt an average abundance 3.4 times higher than that recorded at 1000-1500 m (Carrascal \& Palomino, 2005). The BCT model for F. polatzeki in Inagua shows a steep increase of habitat suitability with altitude up to $1300 \mathrm{~m}$ where it stabilizes, a limit that can be understood considering that only $15.8 \%$ of Inagua is $>1300 \mathrm{~m}$ a.s.1. and $0.28 \%$ above $1500 \mathrm{~m}$. Thus, Inagua imposes an altitudinal restriction to $F$. polatzeki based on orography, but the $1300 \mathrm{~m}$ a.s.l. threshold is not a true biological limit as the data of the recently established small population in La Cumbre demonstrates. The species is able to dwell at higher altitudes in this area (Delgado et al., 2016), and has shown a formidable increase in the number of breeding pairs from two in 2010 to 16 in 2016 (Rodríguez, 2016). Therefore, the altitudinal range of Gran Canaria probably imposes, per se, restrictions to the distribution of the blue chaffinch, assuming that $F$. teydea and $F$. polatzeki share similar abiotic environmental preferences as sibling species.

As for forest structure, the highest habitat suitability for the successful breeding of $F$. polatzeki is attained in woodland stands with more than $21 \mathrm{~m}$ of pine height and tree cover between 35\%-55\%. Practical recommendations can be derived from these results for managing the dense and relatively young pine plantations located above $1300 \mathrm{~m}$ a.s.1. in other areas of Gran Canaria island (La Cumbre, Los Marteles, Moriscos-Galdar). The positive influence of pine height on habitat preferences has been also observed in F. teydea (see Carrascal and Palomino, 
4562005 at a broad scale, and García-del-Rey et al., 2009 at the habitat use level), while the species

457 in Tenerife island is ca. three times more abundant in thinned (53\% tree cover) than in

458 unmanaged (86\%) reafforestations (García-del-Rey et al., 2010). Nevertheless, the most

459 remarkable difference between the habitat preferences of the two taxa is the ability of $F$. teydea

460 to occupy young pine forests during the breeding season (e.g., Carrascal et al., 1992; García-del-

461 Rey and Cresswell, 2005; García-del-Rey et al., 2010), even the non-native Pinus radiata

462 plantations (Carrascal, 1987), with densities ranging from 25 to $170 \mathrm{birds} / \mathrm{km}^{2}$ in woodlands with

463 pine height ranging from 7 to $15 \mathrm{~m}$. Again, the preference for well-developed and open forests of

$464 F$. polatzeki in Inagua may be the consequence of the maturity of the pine forest in this area. This

465 idea is supported by the fact that $F$. polatzeki is able to thrive at higher altitudes in the less

466 mature pine forests of La Cumbre, with a survival and reproductive success very similar to that

467 recorded in Inagua (Rodríguez \& Moreno, 2008; Delgado et al., 2016).

468

\section{Habitat suitability outside the main distribution area}

The favourable environmental conditions for the blue chaffinch identified in Inagua suggest other natural and historic Gran Canaria pine forests that are not suitable for the species, and should be discarded in the population management plans (i.e., habitat management473 restoration or translocations of individuals). This is clearly the case of Tauro and Pilancones 474 forests, for which the predicted very low habitat suitability maps (see Figure S3 of the 475 supplementary material and Fig. 4) reinforces the lack of the species throughout the historical 476 distribution of the species in Gran Canaria island (Martín \& Lorenzo, 2001). On the other hand,

477 Tamadaba forest has more favourable habitat for the species, especially in the upper part of the 478 two main ridges. The existence of suitable habitat for the reproduction of the species agrees with 
479 the recorded historical presence in this area, although always in low numbers up to 1991

480 (Moreno and Rodríguez, 2007), and recent eventual sightings since 2010 (Pascual Calabuig and

481 Felipe Rodríguez, pers. com.). Nevertheless, the antique photos available for the Tamadaba pine

482 forests in the middle of the 20th century (little vegetation cover of a relatively young pine forest;

483 www.fotosantiguascanarias.org), suggest that the species was not abundant in the past. The low

484 amount of highly suitable habitat for the blue chaffinch in Tamadaba means that this area could

485 foster a smaller population than Inagua (see woodland area with habitat suitability $>0.7$ in Fig. 4;

$4866.58 \mathrm{~km}^{2}$ in Inagua for a population of ca. 280 individuals vs. $1.95 \mathrm{~km}^{2}$ in Tamadaba). The

487 potential area could be further reduced considering the fragmentation of highly suitable

488 woodland patches (see Fig. 4 and Figure S2). This is a concern as woodland specialists usually

489 require large patches of continuous well-preserved forests (e.g., Santos, et al., 2002; Fahrig,

490 2003; Devictor et al., 2008), and habitat fragmentation negatively affects the abundance and

491 suitability of an area for birds (e.g., Basile et al., 2016). Nonetheless, Tamadaba should be

492 considered as a potential area for translocations of blue chaffinches, especially those sectors

493 located at higher altitudes, with tall pine trees and higher summer rainfall. Even if in low

494 numbers, this area would add to the two current distribution areas of the species in Gran Canaria.

495 Our approach has several limitations regarding other potentially important habitat and

496 environmental variables that may influence the presence/absence of the blue chaffinch, such as

497 the occurrence of predators (e.g., cats; Moreno and Rodríguez, 2007) or human pressure from

498 recreation and leisure activities in some of the study areas (e.g., the central part of Tamadaba).

499 Moreover, our study is centered on the breeding season and we do not analyze other limiting

500 factors that may affect the blue chaffinch distribution during the wintering season. 


\section{CONCLUSIONS}

503 Given the preference of this species for mature pine forests that are suffering forest

504 dieback as a consequence of climate change (Martín et al., 2015), we may be witnessing the

505 vanishing existence of an endemic woodland bird species in the eastern limit of the Canary

506 forests. Nevertheless, the reintroduction of the species in other suitable pine forests (especially if

507 they are located at higher altitudes), and forest management practices directed to reduce

508 woodland fragmentation and modify habitat structure according to blue chaffinch habitat

509 preferences, may ameliorate or counteract this vanishing trend. Recommendations for the

510 conservation of blue chaffinch in Gran Canaria include the management of pine forests above

$5111100 \mathrm{~m}$ a.s.1. with a summer precipitation of $13-24 \mathrm{~mm}$, by reducing the cover of the canopy

512 layer to $25-50 \%$ with the removal of some pines lower than $15 \mathrm{~m}$ in height. Our results

513 demonstrate that habitat suitability obtained from modelling the location of successful breeding

514 attempts is a good surrogate of the observed local abundance. Thus, habitat suitability can be

515 used for the identification of potential areas for translocations of blue chaffinches or as a cost-

516 effective tool to provide tentative population estimates.

517

518

519

520

ACKNOWLEDGEMENTS

521 Our acknowledgments to Cartográfica de Canarias, S. A. (GRAFCAN, www.grafcan.es) who did 522 provide the cartographic information available in the Canarian Spatial Data Infrastructure

523 (http://www.idecanarias.es/). The solar radiation information available at www.idecan.es belongs

524 to the Instituto Tecnólogico de Canarias Foundation and Dobon`s Technology, SL and its 
525 elaboration has been partially funded by the Ministerio de Insutria, Turismo y Comercio under

526 the National Plan for Scientific Research, Development and Technological Innovation and the

527 European Regional Development Fund (ERDF). We thank very much Joachim Hellmich,

528 Pascual Calabuig, Ruth de Oñate and Felipe Rodríguez for the help provided in carrying out this

529 work. Claire Jasinski and Ana Rey improved the English of the manuscript.

\section{REFERENCES}

533 Acevedo P, Jiménez-Valverde A, Aragón P, Niamir A. 2016. New developments in the study of species distribution. In: Mateo, R, Arroyo, B, García, J.T. (Eds.), Current trends in Wildlife Research, Springer Nature, pp. 151-175.

536

537

538

Barbet-Massin M, Jiguet F, Albert CH, Thuiller W. 2012. Selecting pseudo-absences for species distribution models: how, where and how many? Methods in Ecology and Evolution $3: 327-338$.

Basile M, Valerio F, Balestrieri R, Possillico M, Bucci R, Altea T, De Cinti B, Matteucci G. 2016. Patchiness of forest landscape can predict species distribution better than abundance: the case of a forest-dwelling passerine, the short-toed treecreeper, in central Italy. PeerJ 4:e2398.

BirdLife International. 2016a. Fringilla polatzeki. The IUCN Red List of Threatened Species 2016: e.T103822640A104230366. $\quad$ http://dx.doi.org/10.2305/ IUCN.UK.20163.RLTS.T103822640A104230366.en. 
546 BirdLife International. 2016b. Sitta whiteheadi. The IUCN Red List of Threatened Species 2016:

547

548

549

550

551

552

553

554

555

556

557

558

559

560

561

562

563

564

565

566

567
e.T22711176A90417098.

http://dx.doi.org/

10.2305/IUCN.UK.2016-

$$
\text { 3.RLTS.T22711176A90417098.en. }
$$

BirdLife International. 2016c. Pyrrhula murina. The IUCN Red List of Threatened Species 2016: e.T22720676A90563705. $\quad$ http://dx.doi.org/ 10.2305/IUCN.UK.20163.RLTS.T22720676A90563705.en.

BirdLife International. 2016d. Sitta ledanti. The IUCN Red List of Threatened Species 2016: e.T22711179A94282380. http://dx.doi.org/10.2305/IUCN.UK.20163.RLTS.T22711179A94282380.en.

Bock CE, Zach F. 2004. Avian habitat evaluation: should counting birds count? Frontiers in Ecology and the Environment 2:403-410.

Brawn JD, Robinson SK. 1996. Source-sink population dynamics may complicate the interpretation of long-term census data. Ecology 77:3-12.

Brook BW, Traill LW, Bradshaw CJA. 2006. Minimum viable population sizes and global extinction risk are unrelated. Ecology Letters 9:375-382.

Buckland ST, Anderson DR, Burnham, KP, Laake JL. Borchers, DL, Thomas L. 2007. Advanced distance sampling. Oxford University Press, New York.

Carrascal LM. 1987. Relación entre avifauna y estructura de la vegetación en las repoblaciones de coníferas de Tenerife (Islas Canarias). Ardeola 34:193-224.

Carrascal LM, Aragón P, Palomino D, Lobo J.M. 2015. Predicting regional densities from bird occurrence data: validation and effects of species traits in a Macaronesian Island. Diversity and Distributions 21:1284-1294. 
568 Carrascal LM, Palomino D. 2005. Preferencias de hábitat, densidad y diversidad de las 569 comunidades de aves en Tenerife (islas Canarias). Animal Biodiversity and Conservation $570 \quad 28: 101-119$.

571 Carrascal LM, Seoane J. 2009. Linking density, productivity and trends of an endangered species: the Bonelli's in Spain. Acta Oecologica 35:341-348.

573 Carrascal LM, Tellería JL, Valido A. 1992. Habitat distribution of Canary chaffinches among 574 islands: competitive exclusion or species-specific habitat preferences? Journal of 575 Biogeography 19:383-390.

576 Carrascal LM, Tellería JL. 1991. Bird size and density: a regional approach. American Naturalist 138:777-784.

578 Cody ML. 1985. Habitat selection in birds. Academic Press, London.

579 Conlisk E, Conlisk J, Enquist B, Thompson J, Harte J. 2009. Improved abundance prediction 580 from presence-absence data. Global Ecology and Biogeography 18:1-10.

581 Cribari-Neto F. 2004. Asymptotic inference under heteroskedasticity of unknown form. 582 Computational Statistics and Data Analysis 45:215-233.

583

584

585

586

587

588

589

De'Ath G. 2007. Boosted trees for ecological modeling and prediction. Ecology and Society $88: 243-251$.

Delgado A, Calabuig P, Suárez V, Trujillo D, Suárez-Rancel MM. 2016. Preliminary assessment of the release of captive-bred Gran Canaria Blue Chaffinches Fringilla teydea polatzeki as a reinforcement population. Bird Study 63:554-558.

Devictor V, Julliard R, Jiguet F. 2008. Distribution of specialist and generalist species along spatial gradients of habitat disturbance and fragmentation. Oikos 117:50-514. 
590 Diniz-Filho JA, Bini LM. 2005. Modelling geographical patterns in species richness using 591 eigenvector-based spatial filters. Global Ecology and Biogeography 14:177-185.

592 Dorman CF, McPherson JM, Araújo MB, Bivand R, Bolliger J, Carl G, Davies G, Hirzel, A, Jetz 593 W, Kissling D, Kühn I, Ohlemüller R, Peres-Neto P, Reineking B, Schröder B, Schurr FM, 594 Wilson R. 2007. Methods to account for spatial autocorrelation in the analysis of species 595 distributional data: a review. Ecography 30:609-628.

596 Elith J, Leathwick J, Hastie T. 2008. A working guide to boosted regression trees. Journal of $597 \quad$ Animal Ecology 77:802-813.

598 Fahrig L. 2003. Effects of habitat fragmentation on biodiversity. Annual Review of Ecology $599 \quad$ Evolution and Systematics 34:487-515.

600 García-del-Rey E, Cresswell W. 2005. Density estimates, microhabitat selection and foraging 601 behaviour of the endemic blue chaffinch Fringilla teydea teydea on Tenerife (Canary $602 \quad$ Islands). Ardeola 52:305-317.

603 García-del-Rey E, Gil L, Nanos N, López-de-Heredia U, Gil-Muñoz P, Fernández-Palacios JM. 604 2009. Habitat characteristics and seed crops used by Blue Chaffinches Fringilla teydea in 605 winter: implications for conservation management. Bird Study 56:168-176.

606 García-del-Rey E, Otto R, Fernández-Palacios JM. 2010. Medium-term response of breeding 607 Blue Chaffinch Fringilla teydea teydea to experimental thinning in a Pinus canariensis 608 plantation (Tenerife, Canary Islands). Ornis Fennica 87:180-188.

609 Gaston KJ, Blackburn T. 2000. Pattern and process in macroecology. Blackwell Science, Oxford, 610 UK. 
611 Geldmann J, Barnes M, Coad L, Craigie ID, Hockings M Burgess ND. 2013. Effectiveness of 612 terrestrial protected areas in reducing habitat loss and population declines. Biological $613 \quad$ Conservation 161:230-238.

614 González MN, Rodrigo JD, Suárez CS. 1986. Flora y vegetación del Archipiélago Canario. 615 Edirca, Las Palmas de Gran Canaria.

616 GRASS Development Team. 2015. Geographic Resources Analysis Support System (GRASS) 617 Software, Version 6.4. Open Source Geospatial Foundation.

618 Hanski I, Haila Y. 1988. Singing territories and home ranges of breeding Chaffinches: visual 619 observation vs. radio-tracking. Omis Fennica 65:97-103.

620

Hijmans RJ, Phillips S, Leathwick J, Elith J. 2016. Package 'dismo'. Versión 1.6.9. 621 Downloadable from https://cran.r-project.org/web/packages/dismo/ dismo.pdf

622 IUCN 2001. IUCN red list categories and criteria: Version 3.1. Gland, Switzerland and 623 Cambridge, UK: IUCN Species Survival Commission.

624 Jiménez-Valverde A. 2011. Relationship between local population density and environmental 625 suitability estimated from occurrence data. Frontiers of Biogeography, 3.2:59-61.

626 Jiménez-Valverde A, Diniz F, de Azevedo EB, Borges PAV. 2009. Species distribution models 627 do not account for abundance: the case of arthropods on Terceira Island. Annales Zoologici $628 \quad$ Fennici 46:451-464.

629 Johnson MD. 2007. Measuring habitat quality: a review. Condor 109, 489-504.

630 Koenker R. 2016. Package 'quantreg'. Versión 5.29. Downloadable from https://cran.r$631 \quad$ project.org/web/packages/quantreg/quantreg.pdf

632 Lifjeld JT, Anmarkrud JA, Calabuig P, Cooper JEJ, Johannessen LE, Johnsen A, Kearns AM, 633 Lachlan RF, Laskemoen T, Marthinsen G, Stensrud E, Garcia-del-Rey E. 2016. Species- 
634 level divergences in multiple functional traits between the two endemic subspecies of Blue 635 Chaffinches Fringilla teydea in Canary Islands. BMC Zoology 1:4.

636 Lumley T, Zeileiss A. 2015. Package 'sandwich'. Versión 2.3-4. Downloadable from 637 https://cran.r-project.org/web/packages/sandwich/ sandwich.pdf.

638 Martín A, Lorenzo JA. 2001. Aves del Archipiélago Canario. Francisco Lemus, La Laguna, 639 Tenerife.

640 Martín JL, Marrero MV, del Arco M, Garzón V. 2015. Aspectos clave para un plan de 641 adaptación de la biodiversidad terrestre de Canarias al cambio climático. In: Herrero A, 642 Zavala MA. (Eds.), Los Bosques y la Biodiversidad frente al Cambio Climático: Impactos, 643 Vulnerabilidad y Adaptación en España. Ministerio de Agricultura, Alimentación y Medio 644 Ambiente, Madrid, pp. 573-580.

645 Miller DL. 2016a. Package 'Distance'. Versión 0.9.6. Downloadable from https://cran.r$646 \quad$ project.org/web/packages/Distance/Distance.pdf.

647 Miller DL. 2016b. Package 'mrds'. Versión 2.1.17. Downloadable from https://cran.r$648 \quad$ project.org/web/packages/mrds/mrds.pdf

649 Moreno AC, Rodríguez F. 2007. Pinzón azul. In: J.A. Lorenzo, J.A. (Ed.), Atlas de las aves 650 nidificantes en el archipiélago canario (1997-2003). Dirección General de Conservación de 651 la Naturaleza-SEO/BirdLife. Madrid, 431-434.

652 Pérez I, Anadón JD, Díaz M, Nicola GG, Tella JL, Giménez A. 2012. What is wrong with 653 current translocations? A review and a decision-making proposal. Frontiers in Ecology and 654 the Environment 10:494-501. 
655 Pestano J, Brown RP, Rodríguez F, Moreno A. 2000. Mitochondrial DNA control region 656 diversity in the endangered blue chaffinch, Fringilla teydea. Molecular Ecology 9:1421$657 \quad 1425$.

658 Pulliam HR, Danielson BJ. 1991. Sources, sinks and habitat selection, a landscape perspective on 659 population dynamics. American Naturalist 137:50-66.

660 R Core Team. 2014. R: A language and environment for statistical computing. R Foundation for 661 Statistical Computing, Vienna, Austria. http://www.R-project.org/

662 663

664

665

666

667

668

669

670

671

672

673

674

675

676

677 analysis in macroecology. Ecography 33:46-50.

Revelle W. 2016. Package 'psych'. Versión 1.6.9. Downloadable from https://cran.rproject.org/web/packages/psych/psych.pdf

Ridgeway G, 2016. Package 'gbm'. Versión 2.1.1. Downloadable from https://cran.rproject.org/web/packages/gbm/gbm.pdf

Rodríguez F. 2016. Translocación del pinzón azul de Gran Canaria Fringilla polatzeki. Technical Report, LIFE14 NAT/ES000077.

Rodríguez F, Moreno AC. 2004 Pinzón Azul de Gran Canaria Fringilla teydea polatzeki. In: Madroño, A, González, C, Atienza, J.C. (Eds.), Libro Rojo de las Aves de España. Dirección General para la Biodiversidad y SEO/BirdLife, Madrid, 207-209.

Rodríguez F, Moreno AC. 2008. Breeding biology of the endangered blue chaffinch Fringilla teydea polatzeki in Gran Canaria (Canary Islands). Acta Ornithologica 43:207-215.

Rummel L, Martinez-Abrain A, Mayol J, Ruiz-Olmo J, Mañas F, Jiménez J, Gómez JA, Oro D. 2016. Use of wild-caught individuals as a key factor for success in vertebrate translocations. Animal Biodiversity and Conservation 39:207-219. 
678 Sangster G, Rodríguez F, Roselaar CS, Robb M, Luksenburg JA. 2016. Integrative taxonomy 679 reveals Europe's rarest songbird species, the Gran Canaria blue chaffinch Fringilla 680 polatzeki. Journal of Avian Biology 47:159-166.

681 Santos T, Tellería JL, Carbonell R. 2002. Bird conservation in fragmented Mediterranean forests 682 of Spain: effects of geographical location, habitat and landscape degradation. Biological $683 \quad$ Conservation 105:113-125.

684 Santos A. 2000. La vegetación. In: Morales, G, Pérez-González, R. (Eds.), Gran Atlas Temático 685 de Canarias. Arafo, Tenerife, pp. 121-146.

686 Sing T, Sander O, Beerenwinkel N, Lengauer T. 2015. Package 'ROCR'. Versión 2.1.1. 687 Downloadable from https://cran.r-project.org/web/packages/ROCR/ ROCR.pdf

688 Suárez NM, Betancor E, Fregel R, Rodríguez F, Pestano J. 2012. Genetic signature of a severe 689 forest fire on the endangered Gran Canaria blue chaffinch (Fringilla teydea polatzeki). $690 \quad$ Conservation Genetics 13:499-507.

691 Traill LW, Bradshaw CJA, Brook BW. 2007. Minimum viable population size - A meta-analysis 692 of 30 years of published estimates. Biological Conservation 139:159-166.

693 IUCN. (2012). IUCN Red List Categories and Criteria: Version 3.1. Second edition. Gland, 694 Switzerland and Cambridge, UK: IUCN. iv + 32pp.

695 Van Horne B. 1983. Density as a misleading indicator of habitat quality. Journal of Wildlife $696 \quad$ Management 47:893-901.

697 VanDerWal J, Shoo LP, Johnson CN, Williams SE. 2009. Abundance and the environmental 698 niche: environmental suitability estimated from niche models predicts the upper limit of $699 \quad$ local abundance. American Naturalist 174:282-291. 
700 Vickery PD, Hunter ML, Wells JV. 1992. Is density an indicator of breeding success? The Auk $701 \quad 109: 706-710$.

702 Warton D, Aarts G. 2013. Advancing our thinking in presence-only and used-available analysis. 703 Journal of Animal Ecology 82:1125-1134.

704 Weber MM, Stevens RD, Diniz-Filho JAF, Grelle AEV. 2017. Is there a correlation between 705 abundance and environmental suitability derived from ecological niche modelling? A 706 meta-analysis. Ecography 40: 817-828.

707 Wiens J. 1989. The ecology of bird communities. Volume I: foundations and patterns. 708 Cambridge University Press, Cambridge.

709 Yañez-Arenas C, Guevara S, Martínez-Meyer E, Mandujano S, Lobo JM. 2014. Predicting 710 species' abundances from occurrence data: effects of sample size and bias. Ecological $711 \quad$ Modelling 294:36-41.

712 Zeileis A. 2004. Econometric computing with $\mathrm{HC}$ and HAC covariance matrix estimators. 713 Journal of Statistical Software 11:1-17. 
715 Table 1. Summary of the 20 randomized runs of the boosted classification tree (BCT) models

716 analysing habitat suitability of the nesting location of successful breeding pairs (at least one

717 fledgling per season). The BCT models compare the habitat characteristics in pixels of 50x50 m

718 around nests (59 nests with breeding success recorded in six years from 2011 to 2016) against

719 the same number of pixels of the same size randomly obtained from the pine forests of Inagua

720 reserve. Twelve environmental variables were used in all BCT models (see Table 2).

721

722

723

724

724

725

726

727

728

729

\begin{tabular}{lrrrr} 
& mean & sd & minimum & maximum \\
\hline Number of boosted trees & 4640 & 996.1 & 2800 & 6400 \\
Ten-fold cross-validation AUC & 0.905 & 0.024 & 0.869 & 0.938 \\
Sensitivity & 0.999 & 0.004 & 0.983 & 1.000 \\
Specificity & 0.979 & 0.015 & 0.932 & 1.000 \\
Negative predictive value & 0.999 & 0.004 & 0.983 & 1.000 \\
Positive predictive value & 0.979 & 0.015 & 0.937 & 1.000
\end{tabular}


730 Table 2. Average relative importance (in \%) of the 12 environmental variables used in boosted 731 classification trees models (for more details see Table 1). Results are for 20 randomized runs 732 analysing habitat suitability of the nesting location of successful breeding pairs against the same 733 number of pixels of the same size randomly obtained from the pine forests of Inagua reserve. 734

735

736

\begin{tabular}{lrrrr} 
& mean & sd & minimum & maximum \\
\hline Average pine height & 26.4 & 9 & 10.2 & 49.2 \\
Cover of the canopy (pine) layer & 19.2 & 8 & 7.7 & 37.5 \\
Altitude & 13.7 & 6 & 2.2 & 24.3 \\
Rainfall in July-September & 11.7 & 6 & 3.7 & 25.6 \\
Slope & 5.6 & 3 & 2.8 & 9.6 \\
Incident solar radiation & 5.0 & 3 & 1.7 & 14.5 \\
Northern orientation & 4.4 & 2 & 2.1 & 7.9 \\
Cover of the shrub layer & 4.3 & 1 & 1.5 & 7.4 \\
Average temperature in May & 2.9 & 1 & 1.5 & 4.6 \\
Western orientation & 2.6 & 1 & 1.6 & 4.8 \\
Average height of shrubs & 2.2 & 1 & 0.5 & 5.3 \\
Average temperature in July & 2.0 & 1 & 1.3 & 3.4
\end{tabular}




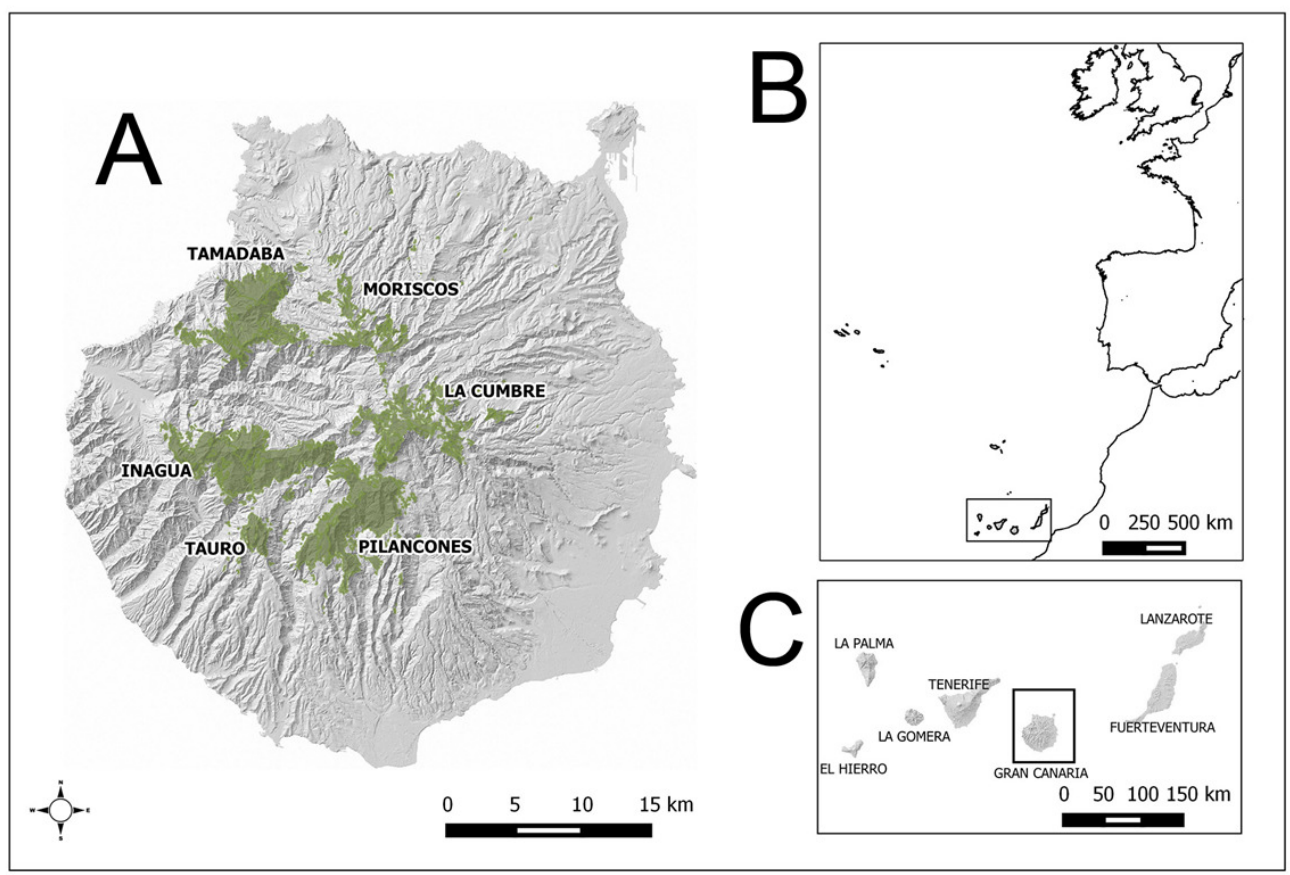

739

740 Figure 1. Study areas (green) in Gran Canaria island (Spain). Other pine forests, outside the 741 altitudinal range of the core distribution area of the blue chaffinch in Inagua, are also shown 742 (Moriscos and La Cumbre; they are pine plantations mainly established after 1960). White dots

743 in Inagua Natural Reserve show the location of nests with successful breeding attempts (at least 744 one chick fledged, and only one nest per breeding pair and year). Black dots show the centre of 745100 units of $229 \mathrm{~m}$ in length of a survey trail of $22.9 \mathrm{~km}$ repeated from 1994 to 2016. 

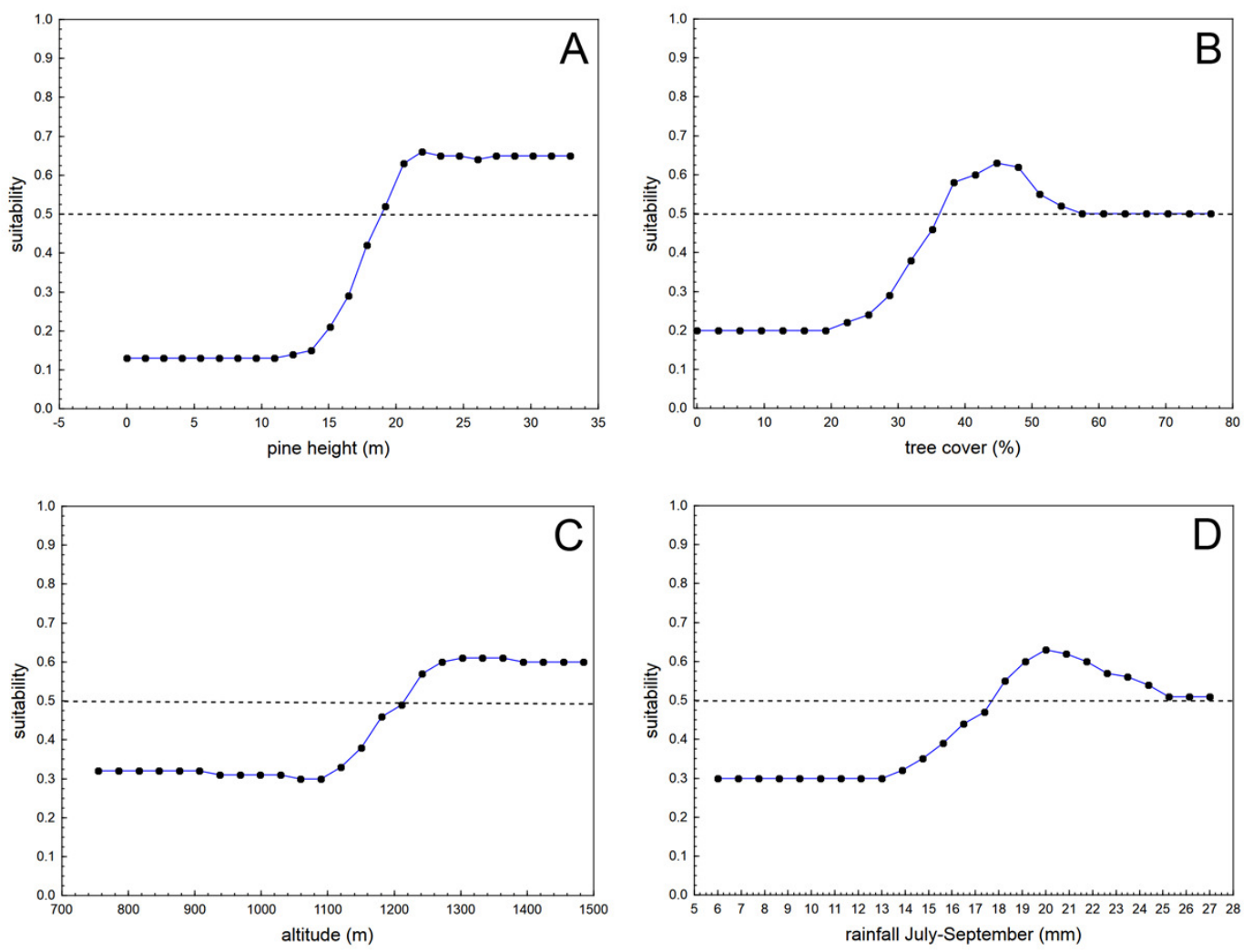

747

748

Figure 2. Average partial dependence plots for the four most influential variables in the 20 randomized runs of boosted classification trees models analysing habitat suitability of the nesting location of successful breeding pairs of blue chaffinches against the same number of pixels of the same size randomly obtained from the pine forests of Inagua reserve. Suitability value of 0.5 denotes random distribution according to each predictor (depicted by means of a dashed line).

754 Values of the predictors with low suitability figures show that those environmental conditions 755 are not favourable for the breeding success of the blue chaffinch in Inagua reserve. See Tables 1 and 2 for more details. 


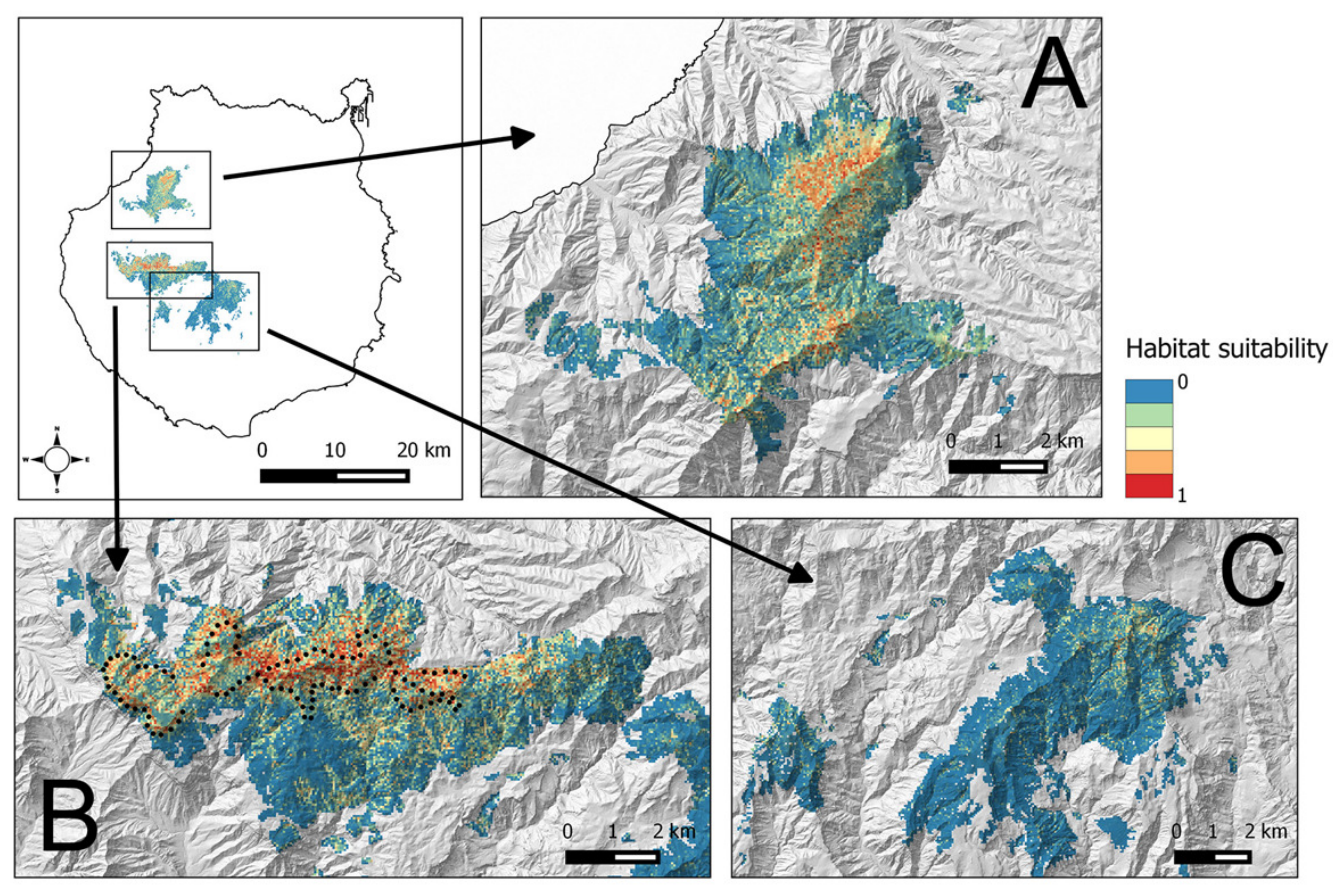

759 Figure 3. Habitat suitability map for the successful breeding of the blue chaffinch in four pine 760 forests of Gran Canaria island located within the altitudinal range of Inagua. The map resolution is $50 * 50 \mathrm{~m}^{2}$ cells. A - Tamadaba, B - Inagua, C - Pilancones and Tauro. 

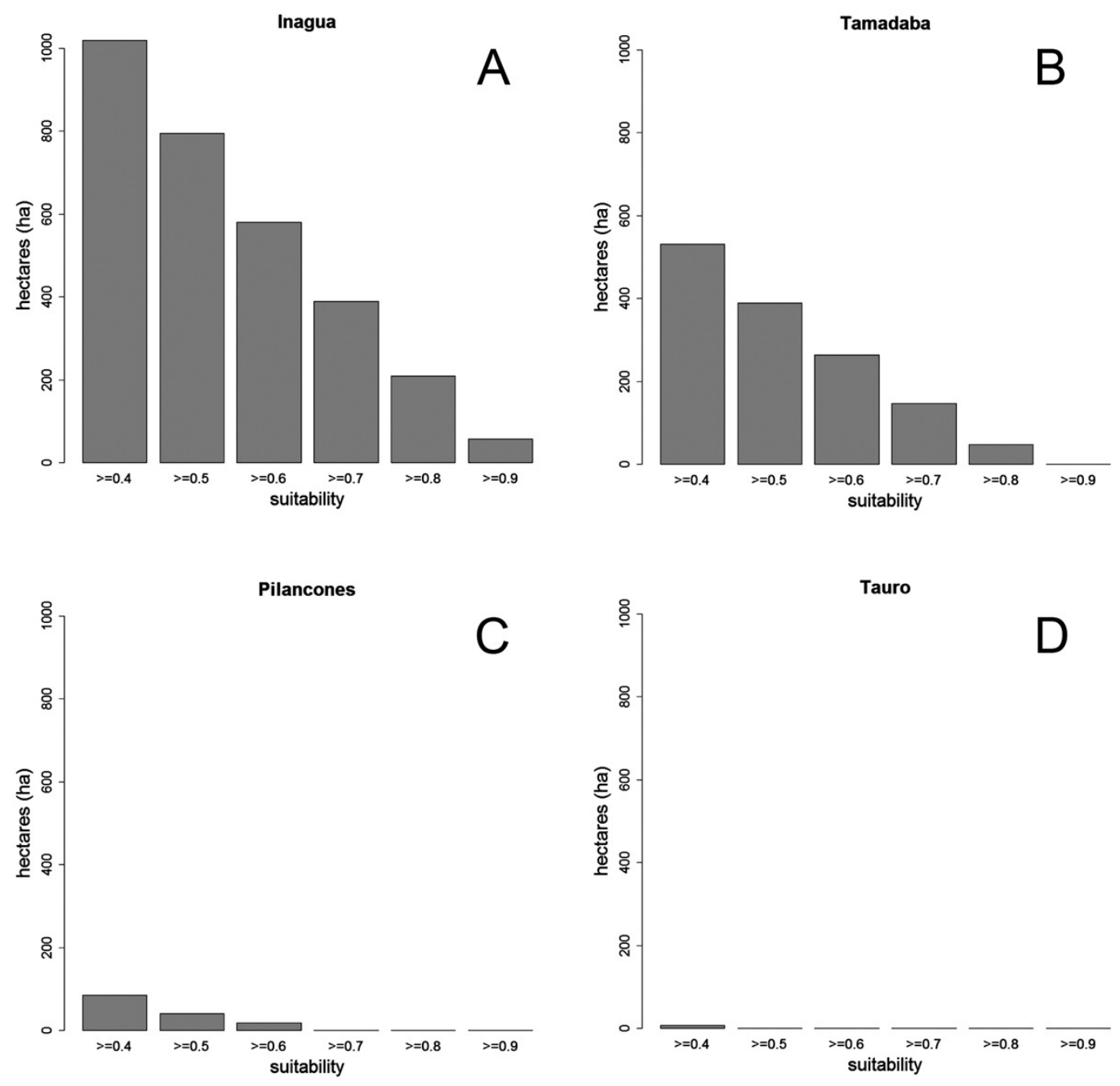

764 Figure 4. Surface (in hectares, ha) of four pine forests of Gran Canaria Island with different 765 levels of habitat suitability for the successful breeding of the blue chaffinch. 


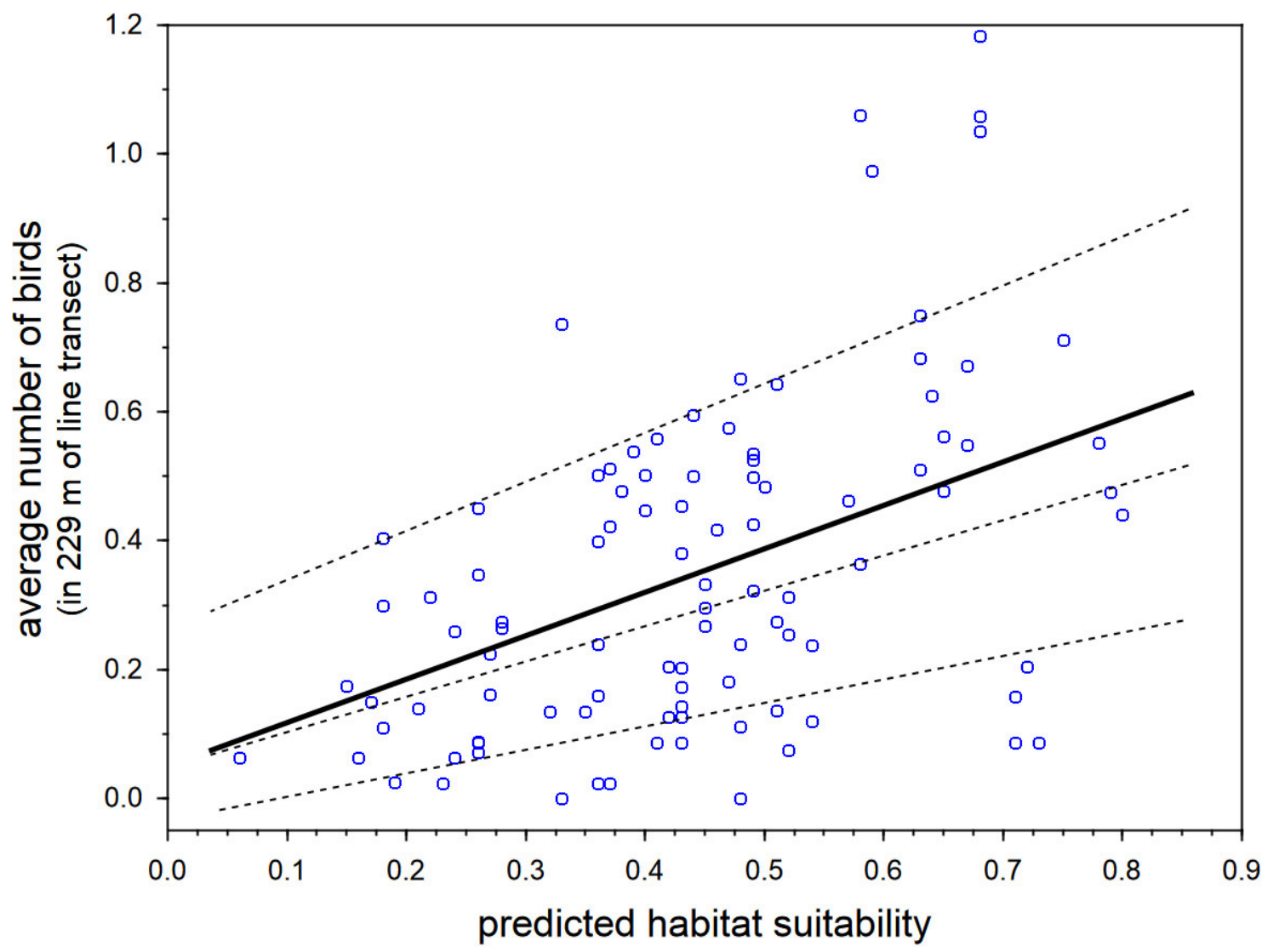

767

768

769 Figure 5. Relationship between the predicted breeding habitat suitability of BCT models and the

770 average number of blue chaffinches counted during the breeding season in 100 transect units of 771 $229 \mathrm{~m}$ along the same $22.9 \mathrm{~km}$ survey trail in Inagua reserve during 15 years (1994-2006 and

772 2011-2016 in those years when the pine forest was not affected by the devastating forest fire of 773 July 2007). The thick line shows the partial OLS regression slope, and the three dashed lines the 774 regression slopes for $90 \%, 50 \%$ and $10 \%$ quantile regressions, after controlling by three spatial 775 filters obtained by means of spatial eigenvector mapping (i.e., the residuals of models do not 776 manifest statistically significant spatial autocorrelation according to Moran’s I). 